\title{
Synthesis and spectroscopic characterization of palladium-doped titanium dioxide catalyst
}

\author{
FERESHTEH CHEKIN ${ }^{1, *}$, SAMIRA BAGHERI ${ }^{2}$ and SHARIFAH BEE ABD HAMID ${ }^{2}$ \\ ${ }^{1}$ Department of Chemistry, Ayatollah Amoli Branch, Islamic Azad University, Amol 678, Iran \\ ${ }^{2}$ Nanotechnology \& Catalysis Research Centre (NANOCAT), IPS Building, University Malaya, \\ 50603 Kuala Lumpur, Malaysia
}

MS received 19 March 2014; revised 5 May 2014

\begin{abstract}
In this work, we reported synthesis of palladium $(\mathrm{Pd})$-doped titanium dioxide $\left(\mathrm{TiO}_{2}\right)\left(\mathrm{Pd}-\mathrm{TiO} \mathrm{O}_{2}\right)$ nanoparticles by the sol-gel-assisted method. The synthesized Pd-doped $\mathrm{TiO}_{2}$ nanoparticles were characterized using $\mathrm{X}$-ray diffraction, transmission electronic microscopy, energy-dispersive spectroscopy, Fourier transform infrared (FTIR) spectroscopy and voltammetry techniques. The analysis showed that particles are spherical in shape and pure

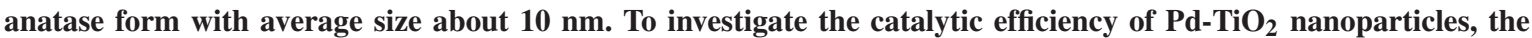
hydrogen evolution reaction using the deposited film of $\mathrm{Pd}_{-} \mathrm{TiO}_{2}$ nanoparticles on glassy carbon electrode (Pd$\mathrm{TiO}_{2}$ /GCE) was studied in $0.1 \mathrm{M} \mathrm{H}_{2} \mathrm{SO}_{4}$ solution using linear scanning voltammetry. This study demonstrates the feasibility of using gelatin for the synthesis of $\mathrm{Pd}-\mathrm{TiO}_{2}$ catalyst.
\end{abstract}

Keywords. Pd-doped $\mathrm{TiO}_{2}$ nanoparticles; gelatin; hydrogen evolution reaction.

\section{Introduction}

Titanium dioxide $\left(\mathrm{TiO}_{2}\right)$ thin films have applications in optics and electronics because of their excellent properties, e.g. chemical and physical stability, high refractive index, high dielectric constants, high electrical resistance and interesting catalytic properties. The catalytic activity of $\mathrm{TiO}_{2}$ is dependent on its crystal structure, crystal size distribution, surface roughness, surface hydroxyl group density, and so on. ${ }^{1}$

Highly dispersed nanoparticles of noble metals, such as Pt, $\mathrm{Pd}, \mathrm{Rh}, \mathrm{Ru}$ and $\mathrm{Au}$ in mesoporous supports as titania, alumina, silica are widely used as catalysts in organic synthesis, petrochemistry, etc. In a study concerning the photocatalytic activity of noble-metal-loaded $\mathrm{TiO}_{2},{ }^{2-8}$ an ohmic contact is formed between the metal and semiconductor. Hence electrons can easily flow to the metal sites on $\mathrm{TiO}_{2}$ under irradiation and the role of the metal is to act as an electron sink and thus to enhance the activity. However, it is difficult to introduce metal nanoparticles into mesopores by traditional impregnation methods, because they tend to deposit richly on outer surface of mesoporous materials and moreover it is difficult to control the loading amount by impregnation. ${ }^{9}$

Various deposition techniques such as electron beam evapouration, ${ }^{10}$ metal organic chemical vapour deposition (MOCVD) ${ }^{11}$ pulsed laser deposition, ${ }^{12}$ reactive sputtering technique, ${ }^{13}$ spray pyrolysis, ${ }^{14}$ hydrothermal process ${ }^{15}$ and sol-gel methods ${ }^{16}$ have been used for production of $\mathrm{TiO}_{2}$ thin films. Besides the above methods, sol-gel technique can be considered as the most influential technique for preparation

*Author for correspondence (fchekin@yahoo.com) of the mesoporous thin layers. It can provide good uniform composition and large specific areas via mild processing conditions. ${ }^{17,18}$ High-purity and homogeneous oxide materials can be prepared by the sol-gel method, based on hydrolysis and polycondensation of metal-organic precursors, that allows an excellent compositional control. Sol-gel method easily allows the preparation of nanocomposite materials such as inorganic matrices in which a metal phase could be highly dispersed. Many studies deal with Pt dopant. ${ }^{19-21}$ Concerning Pd doping, generally, its dispersion by the solgel method was made in $\mathrm{SiO}_{2},{ }^{22,23} \mathrm{Al}_{2} \mathrm{O}_{3}{ }^{24,25}$ and in vitreous matrices. ${ }^{4-8,26}$ There are few references so far regarding the use of $\mathrm{Pd}^{2+}$ as a dopant in the case of a sol-gel prepared $\mathrm{TiO}_{2}$ matrix.

The hydrogen evolution reaction (HER) is an electrochemical process that has received wide attention because of its importance in both fundamental and technological electrochemistry such as fuel cell technology. ${ }^{27,28}$ The search for new and less expensive alternative materials for HER has been a topic of current interest. ${ }^{29-31}$ Deposition of $\mathrm{Pt}$ or $\mathrm{Pd}$ particles on the less expensive materials such as carbon supports reduced the cost of anode materials in the industrial applications.

In this paper, we report on construction of Pt-doped $\mathrm{TiO}_{2}$ nanoparticles $\left(\mathrm{Pd}-\mathrm{TiO}_{2}\right)$ by the green synthesis method. Techniques X-ray diffraction (XRD), transmission electronic microscopy (TEM), energy-dispersive spectrometer (EDS), Fourier transform infrared (FT-IR) spectroscopy and voltammetry were used to characterize the structure and property of the $\mathrm{Pd}-\mathrm{TiO}_{2}$. It was found that $\mathrm{Pd}-\mathrm{TiO}_{2}$ exhibited good catalytic activity toward the hydrogen evolution reaction. 


\section{Experimental}

\subsection{Materials and apparatus}

Titanium tetraisopropoxide with purity $98 \%$ was obtained from Acros Organics. Palladium nitrate was purchased from Aldrich. Glacial acetic acid (100\%) was purchased from Merck. Other reagents were of analytical grade and purchased from Aldrich or Merck and used as received without further purification.

Electrochemical measurements were performed with an Autolab Potentiostat/Galvanostat (Netherlands). The threeelectrode system consists of a $\mathrm{Pd}-\mathrm{TiO}_{2} / \mathrm{GCE}$ as working electrode, $\mathrm{Ag}|\mathrm{AgCl}| \mathrm{KCl}_{3 \mathrm{M}}$ as the reference electrode and a platinum wire as an auxiliary electrode (Metrohm) were used in all voltammetric experiments. Bruker-D8 powder XRD was used for determination of crystal phase identification and estimation of the crystallite size. LEO-Libra 120 microscope was employed for $\mathrm{Pd}-\mathrm{TiO}_{2}$ nanoparticles TEM images. FT-IR spectroscopy studies were carried out with BRUKER FT-IR spectrometer. OXFORD (INCA Energy 400) EDS was used for the elemental analysis and chemical characterization of the sample. Electrochemical measurements were performed with an Autolab Potentiostat/Galvanostat (Netherlands).

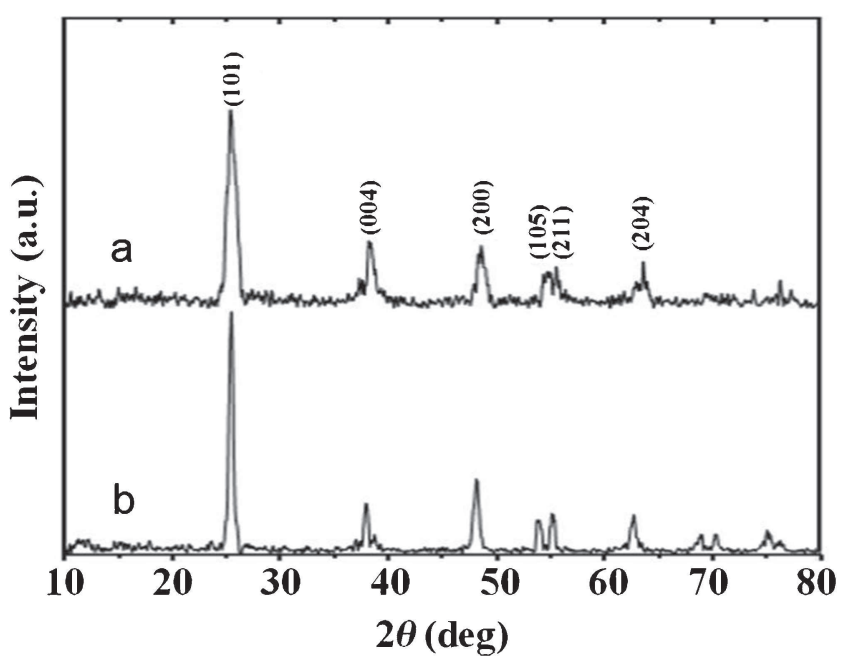

Figure 1. XRD patterns of (a) $\mathrm{Pd}-\mathrm{TiO}_{2}$ and (b) $\mathrm{TiO}_{2}$.

\subsection{Synthesis of $\mathrm{Pd}$-doped $\mathrm{TiO}_{2}$ nanoparticles}

The precursor solution was prepared by dissolving titanium tetraisopropoxide (TTIP) in the glacial acetic acid (AA), followed by the addition of $\mathrm{H}_{2} \mathrm{O}$. The mol ratio of TTIP:AA: $\mathrm{H}_{2} \mathrm{O}$ must be kept at 1:10:200. Gelatin solution was made by dissolving $3.0 \mathrm{~g}$ of gelatin in $100 \mathrm{ml}$ of deionized water and stirred for $30 \mathrm{~min}$ at $60^{\circ} \mathrm{C}$ to achieve a clear gelatin solution. Then, the gelatin solution was added into the precursor solution. Then, $10 \mathrm{ml}$ of $1 \mathrm{M} \mathrm{Pd}$ solution was added drop wise into the precursor solution for a few minutes. The solution was dried at the temperature of $80^{\circ} \mathrm{C}$ overnight. The dried gel was grinded and calcined in a muffle furnace at $500^{\circ} \mathrm{C}$ for $5 \mathrm{~h}$.

\subsection{Fabrication of $\mathrm{Pd}-\mathrm{TiO}_{2} / \mathrm{GCE}$}

Prior to modification, the bare GCE was polished on chamois leather with $0.05 \mu \mathrm{m}$ alumina powder. Then it was thoroughly sonicated in deionized water and absolute ethanol, respectively. One milligram of synthesized $\mathrm{Pd}-\mathrm{TiO}_{2}$ was dispersed in $5 \mathrm{ml}$ dimethyl formamide (DMF) with the aid of ultrasonic agitation. The cleaned GCE was coated by casting $5 \mu \mathrm{l}$ of the $\mathrm{Pd}-\mathrm{TiO}_{2}$ solution and dried at $50^{\circ} \mathrm{C}$ in an oven air to remove the solvent.

\section{Results and discussion}

\subsection{X-ray diffraction and FT-IR spectroscopy}

Figure 1 shows XRD patterns of $\mathrm{TiO}_{2}$ and $\mathrm{Pd}-\mathrm{TiO}_{2}$ powders calcined at $500^{\circ} \mathrm{C}$ under air for $5 \mathrm{~h}$. From the wideangle XRD pattern, the titania samples exist only in anatase phase, with their characteristic diffraction peaks of $2 \theta$ values at about 25.4 (101), 37.9 (004), 48.2 (200), 54.0 (105), 55.1 (211) and 62.9 (204), respectively. In consequence, the prepared $\mathrm{Pd} / \mathrm{TiO}_{2}$ (pattern a) and $\mathrm{TiO}_{2}$ (pattern b) powders are well-crystallized pure anatase form. From the maximum diffraction peak at figure 1 by Scherrer's formula $(D=K \lambda$ / $\beta \cos \theta$, where $D$ is the crystallite size, $K$ the Scherrer constant usually taken as $0.89, \lambda$ the wavelength of the $\mathrm{X}$-ray radiation $(0.15418 \mathrm{~nm}$ for $\mathrm{Cu} \mathrm{K} \alpha)$, and $\beta$ the full-width at halfmaximum of diffraction peak measured at $2 \theta$, the average particle sizes of pure $\mathrm{Pd}-\mathrm{TiO}_{2}$ and $\mathrm{TiO}_{2}$ powders for (101)

Table 1. Compared parameters of $\mathrm{Pd}-\mathrm{TiO}_{2}$ synthesized using different methods.

\begin{tabular}{lcccc}
\hline Method & Template & Particle size $(\mathrm{nm})$ & Synthesized temperature $\left({ }^{\circ} \mathrm{C}\right)$ & Reference \\
\hline Sol-gel dip coating & Pluronic P123 & 7.1 & 500 & 8 \\
Magnetron sputtering & - & 23.4 & 900 & 7 \\
Sol-gel dip coating & - & 30.7 & 500 & 6 \\
Electrospinning & Polyvinyl pyrrolidone & 25.0 & 600 & 32 \\
Sol-gel & Gelatin & 10.0 & 500 & This work \\
\hline
\end{tabular}

aPoly-(ethylene oxide) poly-(propylene oxide) poly-(ethylene oxide). 
plane, are about 10 and $15 \mathrm{~nm}$, respectively. In comparison with XRD pattern of pure $\mathrm{TiO}_{2}$, Pd loaded on $\mathrm{TiO}_{2}$ surface nearly has no influence on crystalline structure. $\mathrm{Pd}$ phase has not been detected in the XRD patterns of $\mathrm{Pd}-\mathrm{TiO}_{2}$ powders, possibly because the $\mathrm{Pd}$ content on $\mathrm{TiO}_{2}$ surface is not enough to form clearly crystalline. A comparison of particle size, temperature and synthesis method of $\mathrm{Pd}-\mathrm{TiO}_{2}$ synthesized in this work with those already reported in literatures is shown in table 1 . As shown, parameters are comparable with other results.

Figure 2 shows the FT-IR spectra of $\mathrm{Pd}^{-\mathrm{TiO}_{2}}$ (pattern a) and $\mathrm{TiO}_{2}$ (curve b) nanoparticles in range of 400$4000 \mathrm{~cm}^{-1}$ which were synthesized via the sol-gel method. In undoped $\mathrm{TiO}_{2}$, the peaks at 431 and $701 \mathrm{~cm}^{-1}$ are for $\mathrm{O}-\mathrm{Ti}-\mathrm{O}$ bonding. The band centered at $1608 \mathrm{~cm}^{-1}$ is characteristic of $\delta-\mathrm{H}_{2} \mathrm{O}$ bending. The broad absorption bands between 400 and $800 \mathrm{~cm}^{-1}$ are mainly ascribed to Ti-O and $\mathrm{O}-\mathrm{Ti}-\mathrm{O}-$ flexion vibration. However, the vibration bands between 1300 and $4000 \mathrm{~cm}^{-1}$ are mainly assigned to the chemisorbed and/or physisorbed $\mathrm{H}_{2} \mathrm{O}$ and $\mathrm{CO}_{2}$ molecules on the surface of the compound. When metal ions are doped to the surface of $\mathrm{TiO}_{2}$, the absorption band transforms and simultaneously new absorption band appears. Upon addition of dopant, a small shift was detected for the stretching vibration of Ti-O. ${ }^{33}$

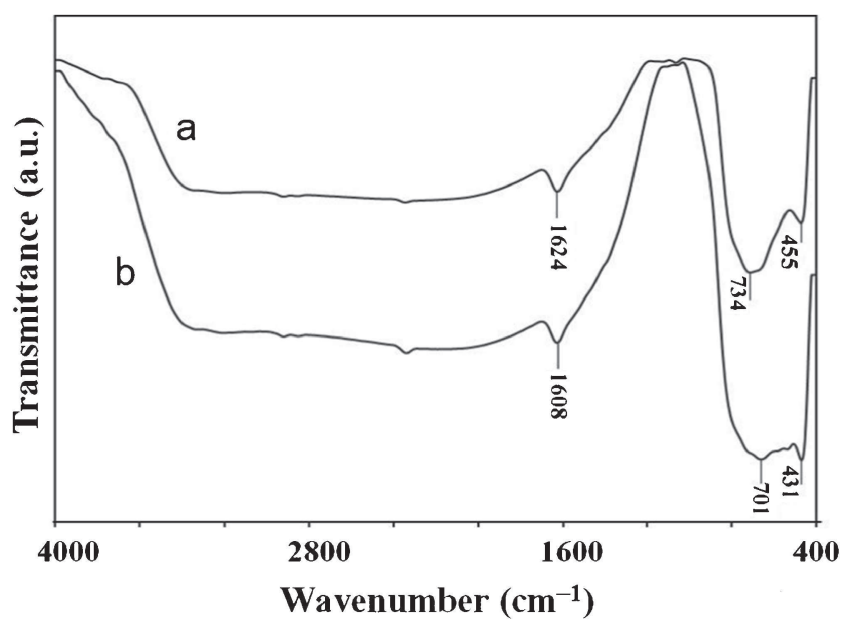

Figure 2. FT-IR patterns of (a) $\mathrm{Pd}-\mathrm{TiO}_{2}$ and (b) $\mathrm{TiO}_{2}$.
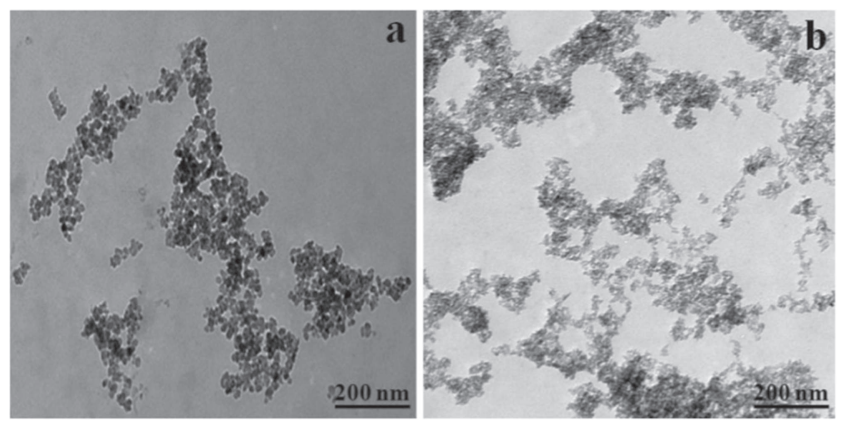

Figure 3. TEM images of (a) $\mathrm{TiO}_{2}$ and (b) $\mathrm{Pd}-\mathrm{TiO}_{2}$.

\subsection{Transmission electronic microscopy and energy- dispersive spectroscopy}

TEM micrographs of $\mathrm{TiO}_{2}$ and $\mathrm{Pd}-\mathrm{TiO}_{2}$ are shown in figure 3. Electron microscopy analyses reveal that $\mathrm{TiO}_{2}$ (image a) and $\mathrm{Pd}-\mathrm{TiO}_{2}$ (image b) samples exhibit similar morphology. As shown in TEM images, particle size of the $\mathrm{Pd}-\mathrm{TiO}_{2}$ is smaller than $\mathrm{TiO}_{2}$. Energy dispersive X-ray spectroscopy (EDS) of $\mathrm{Pd}-\mathrm{TiO}_{2}$ is shown in figure 4 which confirms the existence of $\mathrm{Ti}, \mathrm{O}$ and $\mathrm{Pd}$ with weight percent.

\subsection{Electrochemical behaviour of $\mathrm{Pd}-\mathrm{TiO}_{2} / \mathrm{GCE}$}

The cyclic voltammetry $(\mathrm{CV})$ curve of $\mathrm{Pd}-\mathrm{TiO}_{2} / \mathrm{GCE}$ in $0.1 \mathrm{M} \mathrm{H}_{2} \mathrm{SO}_{4}$ solution at $50 \mathrm{mV} \mathrm{s}^{-1}$ in a potential window of -0.3 to $1.2 \mathrm{~V}$ (figure 5 ) exhibits a typical $\mathrm{H}^{+}$ion electroadsorption/desorption region, a double layer charging current region, a Pd pre-oxidation region and a Pd oxy-species reduction region. In the proton adsorption/desorption region, current peaks observed at $0 \mathrm{~V}$ and $-0.1 \mathrm{~V}$, which corresponds

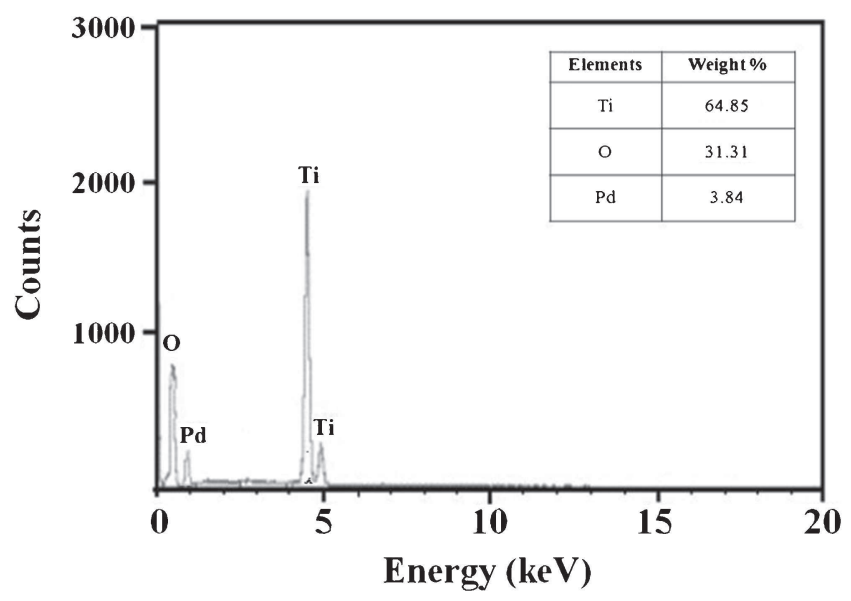

Figure 4. EDAX pattern of $\mathrm{Pd}-\mathrm{TiO}_{2}$.

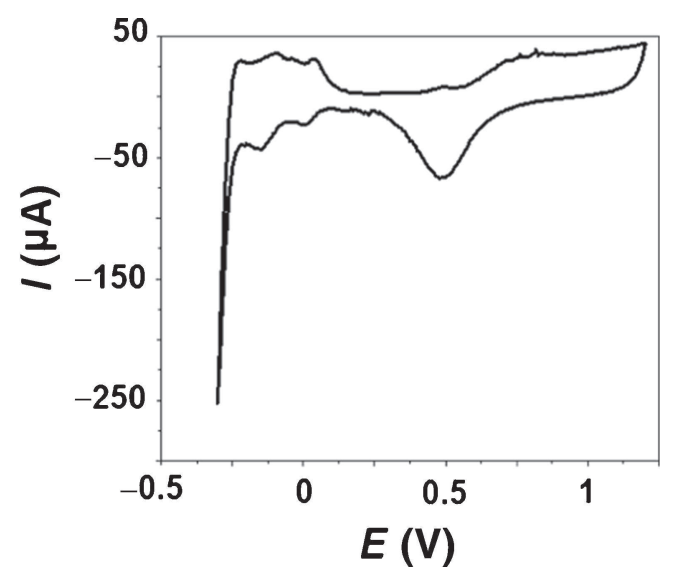

Figure 5. Cyclic voltammogram of $\mathrm{Pd}-\mathrm{TiO}_{2} / \mathrm{GCE}$ in $0.1 \mathrm{M} \mathrm{H}_{2} \mathrm{SO}_{4}$ solution at scan rate $50 \mathrm{mV} \mathrm{s}^{-1}$. 


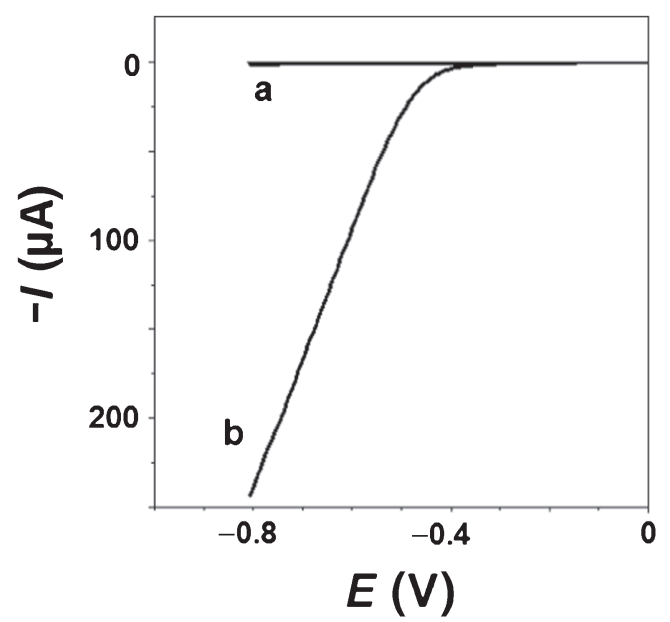

Figure 6. Linear sweep voltammograms of (a) bare GCE and (b) $\mathrm{Pd}-\mathrm{TiO}_{2} / \mathrm{GCE}$ in $0.1 \mathrm{M} \mathrm{H}_{2} \mathrm{SO}_{4}$ at a scan rate of $5 \mathrm{mV} \mathrm{s}{ }^{-1}$.

to polycrystalline $\mathrm{Pd}$, confirmed the existence of $\mathrm{Pd}$, as evidenced by EDS, FT-IR and TEM. The surface concentration of the electroactive Pd on $\mathrm{Pd}-\mathrm{TiO}_{2} / \mathrm{GCE}, \Gamma$ (in $\mathrm{mol} \mathrm{cm}^{-2}$ ), can be estimated using the equation ${ }^{34}$

$$
\Gamma=Q / n F A,
$$

where $Q$ is the charge consumed in Coulombs, obtained from integrating the anodic (or cathodic) peak area in cyclic voltammograms under the background correction. The average $\Gamma$ value of $(1.44 \pm 0.89) \times 10^{-10} \mathrm{~mol} \mathrm{~cm}^{-2}$ was obtained.

\subsection{Electrocatalytic behaviour of $\mathrm{Pd}-\mathrm{TiO}_{2} / \mathrm{GCE}$}

To evaluate the activity of the $\mathrm{Pd}-\mathrm{TiO}_{2}$ catalyst, the electrocatalysis of HER was studied by linear scanning voltammetry (LSV), and results are shown in figure 6. As expected, the electrocatalytic activity improves at surface of $\mathrm{Pd}-\mathrm{TiO}_{2} / \mathrm{GCE}$ (curve b) as though the onset potential of HER occurs at about $-0.4 \mathrm{~V}$ vs. $\mathrm{Ag} \mid \mathrm{AgCl}_{\mathrm{KCCl}} \mathrm{KM}_{3 \mathrm{M}}$ and is indicated by an abrupt increase of the cathodic current. Also, the experiment concerning HER on a bare GCE (curve a) was studied as shown in figure 6. As can be seen, at the same current density, the overpotential of HER at $\mathrm{Pd}-\mathrm{TiO}_{2} / \mathrm{GCE}$ is lower than that at GCE.

\section{Conclusion}

In summary, we demonstrated that $\mathrm{Pd}$-doped $\mathrm{TiO}_{2}$ nanoparticles can be easily formed by the sol-gel method. The analysis showed that particles are spherical in shape and pure anatase form with average size about $10 \mathrm{~nm}$. To investigate the catalytic efficiency of $\mathrm{Pd}-\mathrm{TiO}_{2}$, the hydrogen evolution reaction was studied using the deposited film of $\mathrm{Pd}-\mathrm{TiO}_{2}$ on glassy carbon electrode in $0.1 \mathrm{M} \mathrm{H}_{2} \mathrm{SO}_{4}$ solution using LSV. The electrocatalytic activity improves at surface of $\mathrm{Pd}-\mathrm{TiO}_{2} / \mathrm{GCE}$ as though the onset potential of HER occurs at about $-0.4 \mathrm{~V}$ vs. $\mathrm{Ag}|\mathrm{AgCl}| \mathrm{KCl}_{3 \mathrm{M}}$ and is indicated by an abrupt increase of the cathodic current.

\section{References}

1. Sonawane R S, Kale B B and Dongare M K 2004 Mater. Chem. Phys. 8552

2. Chen H W, Ku Y and Kuo Y L 2007 Water Res. 412069

3. Huang M, Xu C, Wu Z, Huang Y, Lin J and Wu J 2008 Dyes Pigm. 77327

4. Ranjit K T, Varadarajan T K and Viswanathan B $1996 \mathrm{~J}$. Photochem. Photobiol. A: Chem. 96181

5. Crisan D, Drăgan N, Crisan M and Răileanu M 2009 J. Phys. Chem. Solids 692548

6. Mardare D, Iftimie N, Crişan M, Răileanu M, Yildiz A, Coman T, Pomoni K and Vomvas A 2011 J. Non-Cryst. Solids 357 1774

7. Kim S C, Heo M C and Hahn S H 2005 J. Kor. Phys. Soc. 47 700

8. Yarmand B and Sadrnezhaad S K 2010 Optoelectron. Adv. Mater. Rapid Commun. 41572

9. Yuan S, Sheng Q, Zhang J, Chen F, Anpo M and Dai W 2006 Catal. Lett. 10719

10. Bhattacharyya D, Sahoo N K, Thakur S and Das N C 2000 Thin Solid Films $\mathbf{3 6 0} 96$

11. Zhang X W, Zhou M H and Lei L C 2006 Catal. Commun. 7 427

12. Gyorgy E, Socol G, Axente E, Mihailescu I N, Ducu C and Ciuca S 2005 Appl. Surf. Sci. 247429

13. Mardare D, Nica V, Teodorescu C M and Macovei D 2007 Surf. Sci. 6014479

14. Oja I, Mere A, Krunks M, Nisumaa R, Solterbeck C H and Es-Souni M 2006 Thin Solid Films 515674

15. Kambe S, Murakoshi K, Kitamura I, Wada Y, Yanagida S, Kominami H and Kera Y 2000 Sol. Energy Mater. Sol. Cells 61427

16. Cernigoj U, Stangar U L, Trebxe P, Kraxovec U O and Gross S 2006 Thin Solid Films 495327

17. Yun H, Miyazawa K, Honma I, Zhou H and Kuwabara M 2003 Mater. Sci. Eng. C 23487

18. Liu K, Zhang M, Shi K and Fu H 2005 Mater. Lett. 59 3308

19. Facchin G, Carturan G, Campostrini R, Gialanella S, Lutterotti L, Armelao L, Marci G, Palmisano L and Sclafani A $2000 \mathrm{~J}$. Sol-Gel Sci. Technol. 1829

20. López T, Gómez R, Pecci G, Reyes P, Bokhimi X and Novaro O 1999 Mater. Lett. 4059

21. López T, Gómez R, Romero E and Schifter I 1993 React. Kinet. Catal. Lett. 4995

22. López T, Morán M, Navarrete J, Herrera L and Gómez R 1992 J. Non-Cryst Solids 147\&148 753

23. López T, Bosch P, Navarrete J, Asomoza M and Gómez R 1994 J. Sol-Gel Sci. Technol. 1193

24. Othman M R and Sahadan I S 2006 Micropor. Mesopor. Mater. 91145 
25. Noh J, Yang O B, Kim D H and Woo S I 1999 Catal. Today 53 575

26. Carturan G, Facchin G, Gottardi V, Guglielmi M and Navazio G 1982 J. Non-Cryst. Solids 48219

27. Trasatti S 1991 Electrochim. Acta 36225

28. Xu Y H, He G R and Wang X L 2003 Int. J. Hydrogen Energy 28961

29. Shibli S M A and Dilimon V S 2007 Int. J. Hydrogen Energy 321694
30. Karimi Shervedani R and Madram A R 2007 Electrochim. Acta $\mathbf{5 3} 426$

31. Xu Y, Chen C, Wang X and Wang Q 2007 Int. J. Hydrogen Energy 32537

32. Moon J, Park J Ah, Lee Su J, Zyung T and Kim D 2010 Sens. Actuators B 149301

33. Zhang X, Zhou G, Xu J, Bai G and Wang L 2010 J. Solid State Chem. 1831394

34. Laviron E 1979 J. Electroanal. Chem. 100263 